\title{
Analisis Peran Guru dalam Pembelajaran Mata Pelajaran Ekonomi Kelas X di SMA Muhammadiyah Maumere
}

\author{
Samsul H Jaudin', Mohammad Fitri' ${ }^{2}$, Mohammad Amir ${ }^{3}$ \\ ${ }^{1}$ Pendidikan Ekonomi, IKIP Muhammadiyah Maumere \\ e-mail: rhysama7xxcom@gmail.com \\ 2 Pendidikan Ekonomi, IKIP Muhammadiyah Maumere \\ e-mail: zimbonokelagi@gmail.com \\ 3 Pendidikan Ekonomi, IKIP Muhammadiyah Maumere \\ e-mail: ma9353197@gmail.com
}

\begin{abstract}
Education is inseparable from the important role of the teacher. Teachers in education not only play a role as instructors or educators but also teachers have multi roles such as, instructors and educators, teachers as facilitators and mediators, mentors and motivators, learning managers and learning resources, parents and role models, and evaluators and demonstrators. But in reality not all teachers can carry out their roles well in the learning process for example the use of learning methods used by teachers in learning activities that some teachers only use one method in this case lectures etc. or teaching methods that only rely on books, in addition in the learning process the teacher is required to be able to utilize the learning media optimally, so that it will affect the learning process and the objectives to be achieved but not all teachers can use the learning media during the learning process this is also due to the limitations of the learning media provided by the school. As the classroom manager, the teacher should be able to manage the classroom as a learning environment as well as an aspect of the school environment that needs to be organized but sometimes the teacher only carries out his task which is teaching without regard to good classroom management. Besides the teacher also as a model and role model for students, the teacher should be a role model for students to act so that the creation of learning goals is wrong. Teachers should be able to work on learning resources that are useful and can support the achievement of goals and teaching and learning process, both in the form of resource persons, textbooks, magazines or newspapers. Thus, this study aims to determine how the role of teachers in learning economic subjects in class $X$ in SMA Muhammadiyah Maumere and to find out how the learning process of class $X$ economic subjects in SMA Muhammadiyah Maumere. The method in this study is a qualitative
\end{abstract}


method with the aim to understand phenomena that occur holistically with descriptions in the form of words and language in a natural context by utilizing various scientific methods with data reduction techniques, triangulation and drawing conclusions. The results in this study explain how the teacher in carrying out his role not only as a teacher or educator, but in carrying out his duties the teacher has multiple roles such as: Like the teacher as a facilitator and mediator, guide and motivator, learning managers and learning resources, parents and role models, and evaluators and demonstrators. The results of this study also explain how the learning process of economic subjects ranging from planning learning, implementing learning to the assessment of teaching and learning processes.

Keywords: Economics Lesson, Teacher's Role, Learning Process

\begin{abstract}
Abstrak
Pendidikan tidak terlepas dari pentingnya peran guru. Guru dalam pendidikan tidak hanya berperan sebagai pengajar ataupun pendidik melainkan juga guru memiliki multi peran seperti, pengajar dan pendidik, guru sebagai fasilitator dan mediator, pembimbing dan motivator, pengelola pembelajaran dan sumber belajar, orangtua dan teladan, serta evaluator dan demonstrator. Namun pada kenyataannya tidak semua guru dapat menjalankan perannya dengan baik dalam proses pembelajaran misalnya penggunaan metode pembelajaran yang di gunakan guru dalam kegiatan pembelajaran bahwa sebagaian guru hanya menggunakan salah satu metode saja dalam hal ini ceramah dll atau metode mengajar yang hanya berpatokan pada buku, Selain itu dalam proses pembelajaran guru dituntut dapat memanfaatkan media pembelajaran secara optimal, sehingga akan mempengaruhi proses pembelajaran dan tujuan yang akan dicapai akan tetapi tidak semua guru dapat menggunakan media pembelajaran selama proses pembelajaran hal ini juga dikarenakan keterbatasan media pembelajaran yang di sediakan sekolah. Sebagai pengelola kelas, hendaknya guru mampu mengelola kelas sebagai lingkungan belajar serta merupakan aspek dari lingkungan sekolah yang perlu diorganisir namun terkadang guru hanya melaksanakan tugasnya yaitu mengajar tanpa memperhatikan pengelolaan kelas yang baik. Selain itu guru juga sebagai model dan teladan bagi peserta didik, guru hendakknya menjadi panutan siswa dalam bertindak sehingga terciptanya tujuan pembelajaran salah. Guru mampu mengusahakan sumber belajar yang berguna serta dapat menunjang pencapaian tujuan dan proses belajar mengajar, baik yang berupa narasumber, buku teks, majalah ataupun surat kabar. Dengan demikian, penelitian ini bertujuan untuk mengetahui bagaimana peran guru dalam pembelajaran mata pelajaran ekonomi kelas X di SMA Muhammadiyah
\end{abstract}




\begin{abstract}
Maumere dan untuk mengetahui bagaimana proses pembelajaran mata pelajaran ekonomi kelas X di SMA Muhammadiyah Maumere. Metode dalam penelitian ini adalah metode kualitatif dengan tujuan untuk memahami fenomana yang terjadi secara holistik dengan deskripsi dalam bentuk kata kata dan bahasa pada sautu konteks alamiah dengan memanfaatkan berbagai metode ilmiah dengan teknik reduksi data, triangulasi serta menarik kesimpulan. Hasil dalam penelitian ini menjelaskan bagaimana guru dalam menjalankan perannya tidak hanya sebagai pengajar atau pendidik semata, akan tetapi dalam menjalankan tugasnya guru memiliki multi peran seperti: Seperti guru sebagai fasilitator dan mediator, pembimbing dan motivator, pengelola pembelajaran dan sumber belajar, orangtua dan teladan, serta evaluator dan demonstrator. Hasil penelitian ini juga menjelaskan bagaimana proses pembelajaran mata pelajaran ekonomi mulai dari perencanaan pembelajaran, pelaksanaan pembelajaran hingga pada kegiatan penilaian proses belajar mengajar.
\end{abstract}

Kata kunci: Peran Guru, Proses Pembelajaran, Matapelajaran Ekonomi

\title{
PENDAHULUAN
}

Pentingnya pendidikan tertuang dalam Undang-undang Nomor 20 Tahun 2003 tentang Sistem Pendidikan Nasional, Pendidikan merupakan suatu kebutuhan bagi setiap orang untuk mewujudkan harapan dan cita-cita demi kelangsungan hidupnya. Dalam Undang-undang Nomor 20 Tahun 2003 Bab I pasal I dijelaskan bahwa Pendidikan adalah usaha sadar dan terrencana untuk mewujudkan suasana belajar dan proses pembelajaran agar peserta didik secara aktif mengembangkan potensi diri untuk memiliki kekuatan spiritual keagamaan, pengendalian diri, kepribadian, kecerdasan, akhlak mulia, serta keterampilan yang diperlukan diri, masyarakat, bangsa dan negara. Adapun tujuan utama pendidikan di Indonesia ialah untuk mencerdaskan kehidupan generasinya serta untuk membantu mencerdaskan kehidupan bangsa Indonesia. Keberhasilan dalam pendidikan tidak terlepas dari upaya upaya yang dilakukan guru. UU Nomor 14 tahun 2005 tentang Guru dan Dosen, dijelaskan bahwa “Guru adalah pendidik profesional dengan tugas utama mendidik, mengajar, membimbing, mengarahkan, melatih, menilai, dan mengevaluasi peserta didik pada pendidikan anak usia dini 
jalur pendidikan formal, pendidikan dasar, dan pendidikan menengah". Berbicara tentang guru dalam pendidikan maka berbicara tentang peran yang harus dilakukan guru dalam pendidikan. Secara konseptual peran guru dalam proses pembelajaran meliputi banyak hal antara lain pendidik dan pengajar, fasilitator dan mediator, pembimbing, motivator, peneliti, demonstrator, pengelola pembelajaran, sumber belajar, pemimpin, pendorong kreativitas, orang tua dan teladan, emancipator, evaluator (Zahroh 2015:157-186). Saat ini Guru dituntut lebih maju serta lebih pintar dalam memahami perkembangan IPTEK yang sedang berkembang. Dalam pembelajaran ekonomi, guru di tuntut untuk lebih kreatif serta memiliki kepribadian yang inovatif dalam mengembangkan pembelajaran. Hal ini dimaksudkan untuk menciptakan pembelajaran yang kondusif agar peserta didik lebih aktif, kreatif serta senang dalam mengikuti pembelajaran. Dengan demikian maka tujuan pembelajaran dengan sendirinya tercapai.

Melihat permasalahan pendidikan di sekitar kita, terkadang guru hanya memahami perannya dalam proses pembelajaran hanya sebatas seorang pendidik atau pengajar yang tugasnya hanya mengajar dan mendidik ketika berada dilingkungan sekolah. pada kenyataannya tidak semua guru dapat menjalankan perannya dengan baik dalam proses pembelajaran misalnya penggunaan metode pembelajaran dalam proses belajar mengajar sebagian guru hanya berpatokan pada satu metode saja dalam hal ini ceramah dll atau metode mengajar yang hanya berpatokan pada buku, padahal yang seharusnya dalam kurikulum 2013 guru hendakmya berusaha menciptakan pembelajaran yang menyenangkan serta mampu membuat peserta didik untuk lebih aktif dalam proses pembelajaran, yaitu salah satunya dengan penggunaan metode yang bevariasi. Selain itu dalam proses pembelajaran guru dituntut dapat memanfaatkan media pembelajaran secara optimal, sehingga mempengaruhi proses pembelajaran dan tujuan yang dicapai, akan tetapi tidak semua guru dapat menggunakan media pembelajaran selama proses pembelajaran hal ini juga dikarenakan keterbatasan media pembelajaran 
yang di sediakan sekolah. Sebagai pengelola kelas, hendaknya guru mampu mengelola kelas sebagai lingkungan belajar serta merupakan aspek dari lingkungan sekolah yang perlu diorganisir namun terkadang guru hanya melaksanakan tugasnya yaitu mengajar tanpa memperhatikan pengelolaan kelas yang baik. Selain itu guru juga sebagai model dan teladan bagi peserta didik, guru hendakknya menjadi panutan siswa dalam bertindak sehingga terciptanya tujuan pembelajaran salah. Hasil dalam penelitian ini bertujuan untuk mengetahui bagaimana peran guru proses pembelajaran mata pelajaran ekonomi kelas X di SMA Muhammadiyah Maumere. Selain untuk mengetahui peran guru, hasil dalam penelitian ini juga bertujuan untuk mengetahui bagaiman proses pembelajaran yang terjadi di SMA Muhammadiyah Maumere. Adapun manfaat yang dapat di ambil dalam penelitian, secara teoritis penelitian ini diharapkan dapat membantu meningkatkan kualitas pendidikan dengan meningkatkan peran guru dalam proses pembelajaran disekolah. Sedangkan secara praktif, penelitian ini dapat dijadikan sarana untuk mengembangkan dan meningkatkan peran guru dalam pembelajaran sehingga dapat mengoptimalkan tujuan yang ingin di capai. Manfaat lain dari hasil penelitian juga diharapkan dapat menjadi informasi dalam mengembangkan kualitas peran guru serta dapat mengembangkan kualitas proses pembelajaran.

\section{METODE PENELITIAN}

Penelitian ini menggunakan pendekatan kualitatif dengan jenis penelitian deskriptif. Pendekatan kualitatif digunakan peneliti untuk menganalisis "Peran guru dalam proses pembelajaran mata pelajaran ekonomi di SMA Muhammadiyah Maumere. Penelitian ini dilakukan di SMA Muhammadiyah Maumere yang secara keseluruhan terhitung satu bulan, dilaksanakan pada tangggal 10 Maret-10 April 2020. Subjek dalam penelitian ini merupakan seorang guru mata pelajaran ekonomi kelas X di SMA Muhammadiyah Maumere. 
Penelitian ini menggunakan teknik pengumpulan data yang meliputi teknik wawancara, observasi dan dokumentasi. Teknik wawancara digunakan peneliti untuk mencari data yang lebih akurat, baik data yang diperoleh dari guru maupun kepala sekolah. Teknik wawancara yang digunakan peneliti yaitu teknik wawancara terstruktur. Dalam teknik ini sebelum melakukan wawancara peneliti terlebih dahulu menyiapkan instrumen penelitian berupa pertanyaan-pertanyaan sebagai pedoman dengan jawaban alternatif yang telah disiapkan (Sugiyono, 2013: 319). Wawancara dilakukan peneliti untuk mengungkapkan informasi tentang peran guru dalam pembelajaran. Selain itu wawancara juga dilakukan untuk mengetahui proses pembelajaran dikelas secara konseptual. Teknik observasi yang digunakan peneliti yaitu teknik observasi non-partisipan dengan tidak terlibat langsung kegiatan subjek didalam kelas, peneliti hanya mengamati, mencatat, menganalisis dan selanjutnya membuat kesimpulan tentang peran guru dan juga proses pembelajaran mata pelajaran ekonomi dikelas (Sukmadinata, 2012: 220). Dalam penelitian ini teknik observasi dilakukan untuk mengungkapkan, mengumpulkan data, dan untuk mendapatkan informasi terkait peran guru dan proses pembelajaran yang terjadi di SMA Muhammadiyah Maumere. Selain data yang diperoleh dari teknik wawancara dan observasi, peneliti juga mengumpulkan data dengan menggunakan teknik dokumentasi. Dokumentasi digunakan peneliti untuk mengumpulkan data dukungan lain yang berupa foto, video serta arsip atau dokumen lain yang berhubungan dengan peran guru dalam proses pembelajaran mata pelajaran ekonomi di SMA Muhammadiyah Maumere. Teknik dokumentasi merupakan pelengkap dari penggunaan metode observasi dan wawancara dalam penelitian kualitatif (Sugiyono, 2013: 329).

Proses analisis data, peneliti menggunakan analisis data kualitatif dengan model Miles dan Humberman. Berikut menurut (Sugiyono, 2013: 244) langkah langkahnya sebagai berikut, (1) Reduction (reduksi data), reduksi data dalam penelitian ini memfokuskan pada peran guru dalam pembelajaran mata pelajaran 
ekonomi dan proses pembelajaran mata pelajaran ekonomi. Dalam melakukan reduksi data, peneliti berpedoman pada tujuan utama dalam penelitian yakni untuk mengetahui bagaimana peran guru kelas dalam pembelajaran mata pelajaran ekonomi dan juga untuk mengetahui bagaimana proses pembelajaran mata pellajaran ekonomi. Sehingga, peneliti merangkum semua kegiatan inti yang terjadi baik proses kegiatan pembelajaran maupun pernyataan-pernyataan yang didapatkan dari hasil wawancara oleh guru yang bersangkutan agar memberikan gambaran yang jelas mengenai peran guru dalam pembelajaran mata pelajaran ekonomi serta proses pembelajaran mata pelajaran ekonomi di SMA Muhammadiyah Maumere. (2) Display (penyajian data), penyajian data dapat dilakukan dalam bentuk tabel, grafik, phie card, pictogram, dan sejenisnya. Dalam penelitian ini penyajian data mengenai peran guru dalam pembelajaran mata pelajaran ekonomi di SMA Muhammadiyah Maumere. Peneliti menyusun, mengorganisasikan, dan mengatur pola hubungan data yang diperoleh setelah melakukan reduksi data. Penyajian data dilakukan agar memudahkan untuk memahami apa yang terjadi, merencanakan kerja selanjutnya berdasarkan apa yang telah dipahami. (3) Conclusion drawing atau verification (kesimpulan), penarikan kesimpulan dan verifikasi dalam penelitian ini diambil dari hasil analisis data di lapangan, berusaha menggambarkan peran guru dalam pembelajaran serta bagaimana proses pembelajaran mata pelajaran ekonomi yang terjadi di SMA Muhammadiyah maumere. Peneliti merumuskan kesimpulan kemudian memverifikasi hasil data yang diperoleh dilapangan. Kesimpulan diambil setelah menyatukan dan merangkum semua data lapangan kemudian menyajikannya menjadi data yang mudah dipah 


\section{HASIL DAN PEMBAHASAN}

Hasil penelitian ini mengungkapkan peran guru dalam proses pembelajaran mata pelajaran ekonomi serta bagaimana proses pembelajaran mata pelajaran ekonomi yang terjadi di SMA Muhammadiyah Maumere.

1. Peran guru dalam pembelajaran mata pelajaran ekonomi

a. Guru sebagai pengajar dan pendidik, guru harus mampu memberikan contoh atau ilustrasi yang mudah di pahami peserta didik, selain itu guru juga harus mampu memberikan pandangan yang bervariasi terhadap materi yang di ajarkan, menunjukan sikap ramah, sopan santun serta mengarahkan peserta didik untuk bertindak lebih mandiri. Hal ini bertujuan agar tujuan pembelajaran dapat tercapai. Berikut hasil wawancara peneliti dengan Pak Kholiq selaku guru mata pelajaran ekonomi:

"Sebagai seorang pendidik dalam proses pembelajaran maka ada beberapa hal yang dilakukan guru dalam kelas agar materi yang diajarkan bisa di pahami oleh peserta didik, tugas guru tidak hanya menyampaikan ilmu pengetahuan yang dimiliki melainkan juga menunjukan sikap sikap seperti, ramah, disiplin jujur, tanggungjawab serta guru harus mampu membuat ilustrasi dalam proses pembelajaran, mersepon, mendengarkan peserta didik dan guru harus memberikan kebebasan peserta didik untuk berpendapat."

Merujuk pada pendapat yang dikemukakan oleh Zahroh (2015: 159) bahwa "guru sebagai pendidik (educator) yaitu guru harus mampu mendidik peserta didiknya melalui ilmu pengetahuan (knowledge) dan mampu mendidik sesuai dengan nilai-nilai (values) yang positif". Pengetahuan yang dimaksud adalah upaya guru untuk menyalurkan ilmu pengetahuan yang dimilikinya seperti membuat ilustrasi atau contoh yang dapat di pahami peserta didik. Sedangkan mendidik sesuai nilai-nilai adalah dengan menunjukan sikap-sikap yang sesuai dengan nilai dan norma yang berlaku 
misalnya menerapkan sikap disiplin, jujur dan tanggung jawab. Guru sebagai pendidik dan pengajar juga di jelaskan oleh Wahyudi (2012), bahwa guru sebagai pendidik adalah harus memiliki standar kualitas pribadi tertentu, yang mencakup tanggung jawab, wibawa, mandiri dan disiplin, karena dia adalah seorang tokoh yang mempengaruhi diri dan pribadi peserta didiknya baik didalam sekolah maupun diluar sekolah bahkan selama hidup mereka. Artinya peran seorang guru sebagai pengajar dan pendidik tidak hanya berlaku di sekolah, melainkan dalam kehidupan bermasyarakat juga semua hal yang dilakukan guru menjadi pembelajaran bagi peserta didiknya, dalam hal ini sikap dan prilaku guru terhadap lingkungan sekitar.

b. Guru sebagai fasilitator dan mediator, untuk menjadi fasilitator maka guru harus terlebih dahulu merencanakan langkah langkah pembelajaran dalam suatu konsep sistematis. Selain itu guru juga berusaha menyediakan fasilitas berupa media pembelajaran, metode, serta penguasaan materi yang baik agar peserta didik dapat dengan mudah memahami materi yang diajarkan. Sedangkan menjadi mediator maka seorang guru harus mampu menggunakan berbagi media pembelajaran seperti leptop, komputer, proyektor seta media pembelajaran lainnya. Selain menjadi penggunaan media, seorang guru juga harus mampu menjadi media yang dapat digunakan peserta didik. Berikut hasil wawancara peneliti dengan Pak Kholiq selaku narasumber dan guru ekonomi:

"Untuk menjadi fasilitator dan mediator maka guru harus terlebih dahulu merencanakan semua langkah langkah kedalam suatu konsep. selain itu guru juga berusaha menyediakan fasilitas berupa media pembelajaran, metode, dan penguasaan materi agar peserta didik dapat dengan mudah mendapat informasi mengenai materi belajar yang tidak di pahami oleh peserta didik selain itu juga, guru di juga harus mampu menyediakan dan mengoperasikan media pembelajaran". 
Pendapat diatas sejalan dengan pendapat yang dikemukakan oleh Zahro (2015) bahwa "tugas guru tidak hanya menyampaikan informasi kepada peserta didik, tetapi harus menjadi fasilitator yang bertugas memberikan kemudahan belajar (facilitate of learning) kepada seluruh peserta didik selain menyediakan fasilitas, seorang guru juga harus memiliki sejumlah pengetahuan yang cukup tentang bagaimana cara menggunakan media pendidikan". Guru sebagai mediator menurut Zahro (2015), yaitu guru memiliki sejumlah pengetahuan yang cukup tentang bagaimana cara menggunakan media pendidikan. Media pendidikan digunakan guru sebagai alat komunikasi dalam mengefektifkan kegiatan belajar mengajar (KBM). Sumber belajar diataranya berupa majalah, koran, TV serta tokoh masyarakat. Sebagai fasilitator dan mediator dalam pembelajaran diartikan bahwa guru harus memudahkan peserta didik dalam memperolah informasi selama proses pembelajaran selain itu, guru juga mampu menyesuikan diri dengan perkembangan IPTEK agar dapat memberikan informasi terbaru tentang materi yang disampaikan baik dari sumber atau referensi yang beragam. Hal ini juge dilakukan guru ekonomi di SMA Muhammadiyah Maumere, yaitu dengan menggunakan media belajar seperti proyektor, leptop dan handphone untuk memberikan materi atau yang akan dipelajari peserta didik.

c. Guru sebagai pembimbing, untuk menjadi seorang pembimbing, guru dituntut untuk dapat memahami permasalahan belajar yang sedang dihadapi seperta didik. Hal ini diperlukan dalam proses pembelajaran agar guru dapat membimbing dan mengarahkan peserta didik untuk dapat keluar dari kesulitan yang dialaminya serta dapat mendorong peserta didik untuk aktif dalam pembelajaran. Berikut hasil wawancara peneliti dengan Pak Kholiq selaku narasumber dan guru ekonomi: 
"Untuk menjadi pembimbing dalam proses pembelajaran maka guru harus mampu mengidentifikasikan kesulitan belajar pada peserta didik, hal ini dilakukan agar guru dapat membimbing dan mengarahkan peserta didik untuk dapat keluar dari kesulitan tersebut. Salah satu cara yang digunakan adalah mengajukan pertanyaan terkait metari yang di pelajari selain itu guru juga harus mampu membimbing dan mengarahkan peserta didik untuk menyelesaikan masalah, serta membimbing dan mengarahkan peserta didik untuk melakukan hal hal yang positif dalam hidupnya masing masing".

Pendapat diatas merujuk pada teori yang di kemukakan oleh Supardi (2013) bahwa "guru sebagai pembimbing dalam menjalankan perannya mengarahkan, membimbing serta memberikan dorongan agar peserta didik ikut aktif dalam kegiatan pembelajaran". bimbingan dan dorongan di perlukan untuk membantu peserta didik dalam menhadapi kesulitan kesulitan belajar yang di alami peserta didik. Menurut Zahroh (2015), mengatakan bahwa guru harus mampu membimbing peserta didiknya agar dapat menemukan berbagai potensi yang dimilikinya sebagai bekal hidup mereka nanti. Menjadi soerang pembimbing artinya seorang guru harus bersiap mendorong dan mendukung peserta didik selama ia dalam kesulitan baik dalam proses pembelajaran maupun dalam melakukan hal hal positif. Hal ini juga dilakukan guru ekonomi di SMA Muhammadiyah, seperti memberikan kebebasan peserta didik untuk bertanya jika ada materi yang kurang di pahami. Selain itu juga guru membimbing peserta didik dalam melakukan hal hal positif seperti disiplin waktu juga guru mengajak peserta didik untuk beribadah tepat waktu salah satunya shalat sepulang sekolah.

d. Guru sebagai motivator, menjadi motivator artinya tugas guru adalah mendorong peserta didik untuk dapat aktif dalam pembelajaran. Untuk mendorong peserta didik maka guru harus memperjelas tujuan 
pembelajaran, memberikan pujian atas keberhasilan peserta didik, memberikan dukungan saat peserta didik kesulitan dalam proses pembelajaran, serta guru harus mampu menciptakan persaingan dan kerja sama selama proses pembelajaran. Berikut hasil wawancara peneliti dengan Pak Kholiq selaku narasumber dan guru ekonomi:

"Sebagai seorang pengajar maka harus melakukan upaya dalam proses pembelajaran untuk mendorong peserta didik. Untuk mendorong peserta didik maka guru harus memperjelas tujuan pembelajaran, memberikan pujian atas keberhasilan peserta didik, memberikan dukungan saat peserta didik kesulitan dalam proses pembelajaran, guru harus mampu menciptakan persaingan dan kerja sama selama proses pembelajaran".

Motivasi bertujuan untuk membangkitkan minat peserta didik dalam proses pembelajaran. Hal ini dilakukan agar menimbulkan semangat untuk belajar sehingga materi yang disampaikan guru dapat dimengerti dan dipahami oleh peserta didik. Pandangan narasumber terkait peran guru sebagai motivator sejalan dengan teori yang dikemukakan oleh Wina Sanjaya (2006) bahwa motivasi bertujuan untuk membangkitkan keinginan peserta didik untuk mempelajari sesuatu. Motivasi diberikan biasanya dengan memperjelas tujuan yang ingin di capai, membangkitkan minat siswa, menciptakan suasana belajar yang menyenangkan dalam belajar, memberi pujian yang wajar terhadap setiap keberhasilan siswa, berikan penilaian, berilah komentar terhadap hasil pekerjaan siswa, dan ciptakan persaingan dan kerjasama antar siswa dan guru. Menurut Zahroh (2015), mengatakan guru sebagai motivator yang berperan sebagai pembangkit motivasi peserta didik agar mereka selalu semangat belajar dan semangat dalam menuntut ilmu pengetahuan (knowledge). Sebagai motivator yang baik, guru berusaha untuk mengarahkan peserta didik kepada hal-hal yang bermanfaat bagi kehidupan mereka, terutama pada saat KBM berlangsung. 
e. Guru sebagai pengelola pembelajaran, pengelolaan pembelajaran dimaksud adalah upaya guru yang meliputi perencanaan, mengumpulkan bahan pembelajaran dari berbagai sumber belajar, mengatur posisi duduk peserta didik hingga pada pengawasan proses pembelajaran di kelas. Berikut hasil wawancara peneliti dengan Pak Kholiq selaku narasumber dan guru ekonomi:

"Upaya guru melakukan pengelolaan kelas meliputi perencanaan, mengumpulkan bahan pembelajaran maupun sumber belajar, mengatur posisi duduk peserta didik, guru harus mengawasi setiap kegiatan yang dilakukan peserta didik selama proses pembelajaran".

Pendapat diatas sejalan dengan maksud pengelolaan pembelajaran yang dikemukan oleh Zahro (2015) bahwa "peran guru sebagai pengelola pembelajaran (learning manager) yakni guru berperan dalam menciptaan iklim belajar yang nyaman lagi menyenangkan bagi peserta didik untuk belajar". Pengelola pembelajaran menurut Wina Sanjaya (2006) guru berperan dalam menciptakan iklim belajar yang memungkinkan siswa dapat belajar secara nyaman. Melalui pengelolaan kelas yang baik guru dapat menjaga kelas agar tetap kondusif untuk terjadinya proses belajar bagi seluruh siswa. Untuk menciptakan iklim pembelajaran yang menyenangkan, maka guru harus terlebih dahulu untuk merencanakan konsep pembelajaran terlebih dahulu. Pembelajaran yang nyaman lagi menyenangkan akan terbentuk jika dipenuhi melalui pengelolaan kelas yang baik. Pengelolaan kelas yang baik akan meningkatkan keberhasilan tujuan pembelajaran.

f. Guru sebagai sumber belajar, Guru merupakan salah satu sumber belajar tetapi bukan satu satunya, untuk itu guru harus mengumpulkan dan mengorganisasikan berbagai macam sumber belajar serta guru juga harus memiliki informasi informasi terbaru mengenai materi yang di akan di sampaikan. Selain itu guru di tuntut untuk mampu menguasai dengan baik 
setiap materi yang akan diajarkan. Untuk pembelajaran kurikulum 2013 guru dituntut memiliki berbagai macam referensi pembelajar yang dapat dirokemendasi untuk menunjang proses pembelajaran. Berikut hasil wawancara peneliti dengan Pak Kholiq selaku narasumber dan guru ekonomi:

“Guru harus mampu mengorganisasikan berbagai sumber belajar menjadi satu bahan ajar yang terpadu, guru harus mampu menguasai dengan baik setiap materi yang akan diajarkan, sebelum proses pembelajaran guru terlebih dahulu membuat pemetaan terhadap materi yang akan di ajarkan, guru juga harus bisa memberikan rokemendasi sumber belajar lain kepada peserta didik seperti internet dan buku buku tertentu untuk menunjang proses pembelajaran"

Pendapat narasumber diatas merujuk pada teori yang di kemukakan oleh Wina Sanjaya (2006) bahwa peran guru sebagai sumber belajar merupakan peran yang sangat penting. Peran sebagai sumber belajar berkaitan erat dengan penguasaan materi pelajaran. Kemampuan guru dalam mengoranisasikan sumber belajar juga sangat di perlukan dalam pembelajaran. Menurut Zahro (2015) untuk menjadi sumber belajar, maka guru hendaknya memiliki bahan referandi yang banyak juga Guru perlu melakukan pemetaan tentang materi pelajaran. Hal ini juga berdasarkan hasil observasi peneliti dikelas selama proses pembelajaran Guru menggunakan buku paket selain itu guru juga menggunakan internet untuk mencari informasi informasi yang dipelajari, guru memperbolehkan peserta didik untuk menggunakan hp sebagai alat bantu untuk mencari sumber belajar lain, guru menjelaskan materi dengan tidak monoton, selain itu guru menjelaskan materi yang intonasi yang jelas dan tidak kaku, penjelasan yang di berikan guru kaya akan informasi. 
g. Guru sebagai orangtua dan teladan, Guru merupakan panutan bagi setiap peserta didik hal ini berarti guru harus memperhatiakn penampilannya baik di sekolah maupun di lingkungan sekitar, guru juga harus memperhatikan setiap tuturkatanya, serta bagaimana guru tersebut bertindak yang sesuai dengan aturan dan norma yang berlaku baik di kehidupan masyarakat maupun kehidupan formal. Berikut hasil wawancara peneliti dengan Pak Kholiq selaku narasumber dan guru ekonomi:

"Untuk menjadi orang tua sekaligus teladan bagi setiap peserta didik terutama saat proses pembelajaran maka seorang guru harus benar benar memperhatikan penampilannya yaitu menggunakan pakaian yang rapi, sopan, juga sesuai dengan aturan yang di tetapkan oleh sekolah. Selain penampilan guru juga dalam proses pembelajaran perlu memperhatikan tuturkatanya yaitu penggunaan bahasa yang sopan dan tidak kasar terhadap peserta didiknya. Serta semua tindakan yang dilakukan guru selama proses pembelajaran yaitu selalu memberikan salam, serta doa sebelum memulai KBM, bersikap jujur, amanah, serta menghargai setiap individu yang ada".

Hasil wawancara diatas dapat di simpulkan bahwa menjadi teladan dan orang tua maka guru harus menunjukan menunjukan sikap sikap yang terpuji baik dari segi penampilan, tuturkata maupun prilaku guru tersebut karena bagi peserta didik guru merupakan orang dapat menjadi teladan yang baik. Selain itu juga guru dapat menjadi orang tua kedua ketika peserta didik di sekolah sehingga setiap prilaku dan tindakan guru akan menjadi contoh bagi peserta didiknya. Pendapat tersebut sejalan dengan teori yang disampaikan oleh Zahroh (2015) bahwa menjadi guru adalah pekerjaan yang mulia, segala perilakunya akan dicontoh dan ditiru peserta didik. Selain Zahro, menurut Sardiman (2012), Sebagi teladan, tentu saja pribadi dan apa yang dilakukan guru akan mendapat sorotan peserta didik serta orang di 
sekitar lingkungannya yang menganggap atau mengakuinya sebagi guru. Artinya Guru adalah sumber keteladanan yang tiada henti, yaitu suatu pribadi yang penuh dengan contoh teladan bagi peserta didik sampai akhir hanyat. Hal ini disebabkan guru berperan sebagai orang tua kedua peserta didik. Sebagai orang tua kedua bagi peserta didik, guru perlu berusaha sekuat tenaga agar dapat menjadi teladan yang baik untuk peserta didik dan masyarakat. Segala tingkah laku, perbuatan, dan cara-cara berbicara guru akan mudah ditiru atau diikuti oleh peserta didik.

h. Guru sebagai evaluator, guru dalam proses pembelajaran harus mampu untuk mengukur tingkat keberhasilan peserta didik. Untuk itu hal perlu dilakukan guru adalah dengan memberikan tes baik tes lisan maupun tes tertulis bisa juga berupa ulangan harian maupun ulangan tengah semester dan ujian semester. Untuk kurikulum 2013 penilaian juga dilakukan terhadap aspek sikap, pengetahuan dan keterampilan". Berikut hasil wawancara peneliti dengan Pak Kholiq selaku narasumber dan guru ekonomi:

"Untuk menilai tingkat keberhasilan peserta didik dilakukan dengan ujian tertulis baik pilihan ganda maupun essay, penilaian sikap peserta didik dengan lember observasi yang di gunakan guru maupun jurnal kelas yang digunakan untuk menilai prilaku peserta didik saat KBM sedang berlangsung, juga penilain ketrampilan peserta didik dengan melihat kemampuan pesesrta didik dalam menyelesaikan proses pembelajaran".

Penilaian yang dilakukan guru terkadang hanya terfokus pada penilaian aspek pengetahuan yang tercermin dalam hasil belajar peserta didik sehingga menimbulkan kesan objektif dalam penilian tersebut. Dalam kurikulum 2013 diharapkan bahwa penilaian tidak hanya dilihat dari aspek pengetahuan saja tetapi juga dilihat dari aspek sikap, prilaku dan ketrampilan peserta didik. Menurut Zahroh (2015), mengatakan melalui 
proses evaluasi, guru dapat mengetahui keberhasilan, pencapaian, dan penguasaan materi yang telah disampaikan. Adanya evaluasi guru dapat mengetahui adanya kelemahan dan kekurang dalam proses pembelajaran. Hal ini dilakukan agar penilaian yang diberikan guru tidak terkesan subjektif karena menilai berdasarkan aspek pengetahuan. Menurut Supardi (2013) Guru sebagai evaluator tidak hanya menilai produk atau hasil belajar, tetapi juga menilai proses atau jalannya pembelajaran. Sehingga, dari kedua kegiatan ini akan mendapatkan umpan balik tentang pelaksanaan pembelajaran yang telah dilakukan. Guru harus memberikan penilaian dalam dimensi yang luas, penilaian terhadap kepribadian peserta didik tentu lebih diutamakan daripada penilaian jawaban peserta didik ketika diberikan tes. Penilaian yang di berikan guru ekonomi di SMA Muhammdiyah berupa pertanyaan lisan maupun tes tertulis juga penilaian sikap melalui jurnal juga penilaian penampilan yang di lihat dari tanggungjawab peserta didik dalam mengerjakan tugas kelompok.

i. Guru sebagai demonstrator, menjadi demonstaror artinya memberikan contoh yang dapat dengan mudah dipahami oleh peserta didik selama proses pembelajara. Upaya yang dilakukan guru sebagai demonstrator adalah dengan memberikan contoh atau gambaran nyata tentang materi yang diajarkan. Selain itu guru juga dapat menjadikan hal hal yang terjadi di lingkungan sekitar sebagai contoh dalam menyampaikan materi. Berikut hasil wawancara peneliti dengan Pak Kholiq selaku narasumber dan guru ekonomi:

"Kesuksesan guru sebagai demonstrator dilihat dari hal hal yang dilakukan dalam proses pembelajaran yaitu kepenguasaan guru terhadap materi yang disampaikan dan tidak ragu ragu, guru juga harus menjadi pelajar dalam proses pembelajaran, guru harus mampu 
memberikan contoh nyata yang berkaitan dengan materi yang dipelajari”.

Hal ini berarti guru dituntut tidak hanya sekedar mengajar melainkan juga memerikan contoh yang mudah dipahami oleh peserta didik. Selain itu guru juga harus benar benar menguasai materi yang akan disampaikan kepada peserta didik. Dengan demikian peserta didik dapat belajar juga percaya aakan kebenaran dari materi yang disampaikan. Menurut Wina Sanjaya (2014) peran guru sebagai demonstrator adalah peran untuk mempertunjukan segala sesuatu yang dapat membuat siswa lebih mengerti dan memahami setiap pesan yang disampaikan. Sebagai demonstrator, guru memiliki peran dalam memperagakan apa yang hendak disampaikan dan diajarkan memiliki efek pada peningkatan kemampuan menuju ke tingkat keberhasilan yang lebih baik. Demonstrasi yang di berikan bertujuan untuk membantu peserta didik untuk memahami apa yang di sampaikan oleh guru.

2. Proses pembelajaran mata pelajaran ekonomi

Upaya pemenuhan standar proses pembelajaran juga dilakukan oleh guru mata pelajaran ekonomi di SMA Muhammadiyah Maumere. Hal ini merujuk pada Permen No. 22 tahun 2016 tentang standar proses. Pelaksanaan pembelajaran merupakan implementasi dari RPP yang meliputi kegiatan pendahuluan, kegiatan inti dan kegiatan penutup.

a. Kegiatan pendahuluan: guru memberikan salam lalu guru menyiapkan peserta didik dengan meminta salah satu peseta didik untuk memimpin doa sebelum memulai proses pembelajaran setelah guru menyiapkan peserta didik guru juga memberikan motivasi untuk membangkitakan semangat dan dorongan untuk mempelajari materi yang akan disampaikan, biasanya motivasi yang diberikan guru berupa mengaitkan manfaat dari materi yang dipelajari dengan kehidupan dilingkungan sekitar. Selain guru memberikan motivasi guru juga memberikan pertanyaan pertanyaan lisan terkait materi 
yang telah dipelajari sebelumnya. Hal ini dilakukan guru untuk membangkitkan ingatan peserta didik terkait materi yang telah dipelajari sebelumnya dan menghubungkan materi yang telah dipelajari dengan materi yang akan di pelajari. Dan yang terakhir guru menjelaskan tujuan pembelajaran dari materi yang akan dipelajari.

b. Kegiatan inti: proses pembelajaran dilaksanakan sesuai dengan tujuan pembelajaran tujuan pembelajaran biasanya meliputi 3 aspek yaitu aspek sikap, aspek pengetahuan, dan aspek ketrampilan. Dalam kegiatan inti peran guru hanya membimbing dan mengarahkan proses pembelajaran serta memberikan arahan arahan yang harus dilakukan peserta didik. Proses pembelajaran dilaksanakan sesuai dengan kurikulum 2013 yaitu peran peserta lebih aktif dibandingkan peran guru selama proses pembelajaran guru hanya memberikan arahan arahan jika peserta didik mengalami kesulitan dalam belajar. Guru menggunakan model pembelajaran Problem basic learning (PBL) dengan metode tanya jawab dan diskusi. Proses pembelajaran dimulai ketika guru memberikan sebuah topik permasalahan yang sesuai dengan materi pembelajaran kemudian peserta didik diminta untuk berperan aktif dalam mengidenfikasikan masalah tersebut, mengumpulkan data data terkait materi yang dipelajari baik dari buku maupun menggunakan HP sebagai sumber lain untuk membantu mengumpulkan data, mengolah data data yang telah dikumpulkan, menyimpulkan data yang telah diolah dan mempresentasikan data atau informasi yang telah dikumpulkan dan ditanggapi oleh peserta didik lain atau kelompok lain. Setelah kegiatan Tanya jawab oleh peserta didik guru memberikan informasi tambahan berupa meluruskan jawaban dari kelompok kelompok yang berpresentasi dan memberikan jawaban atas pertanyaan yang belum terjawab. 
c. Kegiatan penutup: Dalam kegiatan penutup, guru bersama peserta didik baik secara individual maupun kelompok melakukan refleksi untuk mengevaluasi seluruh rangkaian aktivitas pembelajaran dan hasil-hasil yang diperoleh untuk selanjutnya secara bersama menemukan manfaat langsung maupun tidak langsung dari hasil pembelajaran yang telah berlangsung, guru memberikan umpan balik berupa pertanyaan tentang materi yang baru saja di pelajari untuk mengetahui proses dan hasil pembelajaran, guru melakukan kegiatan tindak lanjut dalam bentuk pemberian tugas, baik tugas individual maupun kelompok dan menginformasikan rencana kegiatan pembelajaran untuk pertemuan berikutnya.

Sebelum melaksanakan proses pembelajaran, guru dituntut untuk memiliki perencanaan pembelajaran yang meliputi penyediaan silabus dan rencana pelaksanaan pembelajaran (RPP). Hal ini juga dilakukan guru ekonomi di SMA Muhammadiyah Maumere yaitu dengan menyusun rencana pelaksanaan pembelajaran (RPP) yang sesuai dengan silabus yang diberikan. Pelaksanaan kegiatan pembelajaran mata pelajaran ekonomi di SMA Muhammadiyah Maumere sesuai dengan langkah langkah yang telah dirancanakan dalam rencana pelaksanaan pembelajaran (RPP) yang telah di siapkan, mulai dari kegiatan pendahuluan, kegiatan inti hingga pada kegiatan penutup. Proses penilian pembelajaran dan hasil belajar yang dilakukan guru ekonomi mengacu pada Permen No 23 tahun 2016 tentang standar penilaian yang secara garis besar meliputi aspek aspek yang dinilai serta teknik dan instrument yang dinilai. Aspek yang dinilai guru ekonomi dalam proses pembelajaran meliputi aspek sikap, pengetahuan dan ketrampilan. Instrument yang diigunakan untuk menilai aspek sikap berupa lembar observasi dan juga jurnal kelas. Adapun instrument yang digunakan untuk menilai aspek pengetahuan berupa tes tertulis yang meliputi tes essay dan pilihan ganda serta tes lisan berupa pertanyaan pertanyaan yang diberikan guru selama proses pembelajaran. 
Sedangkan instrument yang untuk menilai aspek keterampilan berupa lember unjuk kerja maupun portofolio.

\section{KESIMPULAN}

Setelah dilakukan penelitian dan analisis data maka dapat disimpulkan bahwa peran guru dalam pembelajaran mata pelajaran ekonomi kelas X di SMA Muhammadiyah Maumere berjalan dengan baik. Hal ini terlihat dari hasil wawancara yang dilakukan peneliti dengan narasumber dan observasi peneliti terhadap proses pembelajaran yang menunjukan bahwa guru ekonomi berperan baik dalam proses pembelajaran.

Peran guru dalam proses pembelajaran. Guru tidak hanya berperan sebagai pengajar dan pendidik akan tetapi guru juga memiliki multi seperti peran guru sebagai pengajar dan pendidik, guru sebagai fasilitator dan mediator, guru sebagai pembimbing, guru sebagai motivator, guru sebagai pengelola pembelajaran, guru sebagai sumber belajar, guru sebagai orang tua dan tauladan, guru sebagai evaluator, guru sebagai demonstrator.

Selain peran guru dalam proses pembelajaran, hasil dalam penelitian ini juga menjelaskan bagaimana proses pembelajaran mata pelajaran ekonomi di SMA Muhammadiyah Maumere. Proses pembelajaran mata pelajaran di SMA Muhammadiyah Maumere berjalan sesuai dengan langkah langkah yang telah ditetapkan. Langkah langkah yang dimaksud mulai dari perencanaan pembelajaran terkait penyediaan silabus dan RPP sebelum mengajar hingga pada penilaian proses pembelajaran. Proses pembelajaran disusun secara sistematis dalam sebuah rancangan pembelajaran mulai dari tujuan pembelajaran hingga pada evaluasi tujuan pembelajaran.

\section{DAFTAR RUJUKAN}

Depdiknas. 2010. Undang-undang RI Nomor 20 Tahun 2003 tentang Sistem Pendidikan Nasional. Jakarta: Depdiknas. 
Peraturan Mentri Nomor 22 Tahun 2016 tentang Standar Proses Pendidikan. Jakarta: Depdiknas.

Peraturan Menteri Nomor 23 Tahun 2016 tentang standar penilaian. Jakarta: Depdiknas.

Sanjaya, Wina. 2006. Strategi Pembelajaran. Jakarta: Kencana Prenamedia Group. Sanjaya, Wina. 2014. Startegi pembelajaran. Jakarta: Kencana Prenamedia Group. Sardiman. 2014. Interaksi dan Motivasi Belajar Mengajar. Jakarta: PT Raja Grafido Persada.

Sugiyono. 2013. Metodologi Penelitian Pendidikan. Bandung: Alfabeta.

Sukmadinata, Nana Syaodih. 2012. Metode Penelitian Pendidikan. Bandung: PT Remaja Rosdakarya.

Supardi. 2013. Kinerja Guru. Bandung: Raja Grafindo Persada.

Undang-undang Nomor 14 Tahun 2005 tentang Guru dan Dosen. Jakarta: Depdiknas.

Wahyudi, Imam. 2012. Mengejar profesionaliseme guru strategi praktis citra guru professional. Jakarta: Prestasi Jakarta.

Zahroh, Aminatul. 2015. Membangun Kualitas Pembelajaran Melalui Dimensi Profesionalisme Guru. Bandung: Yrama Widya. 